\title{
ATIVIDADE VIRAL DO VÍRUS RESPIRATÓRIO SINCICIAL BOVINO (BRSV) EM BEZERROS LEITEIROS
}

\author{
INGRID BORTOLIN AFFONSO ${ }^{1}$, SANDRA POSSEBON GATTI ${ }^{2}$, ANDRÉA SOUZA RAMOS DE MEDEIROS ${ }^{3}$, \\ MARIA DA GLÓRIA BUZINARO ${ }^{4}$, SAMIR ISSA SAMARA ${ }^{4}$ \\ ${ }^{1}$ Pós-graduandas da Faculdade de Ciências Agrárias e Veterinárias da Universidade Estadual Paulista, Jaboticabal, SP, \\ Brasil. \\ ${ }^{2}$ Professora doutora do Colégio Técnico Agrícola " José Bonifácio" da Faculdade de Ciências Agrárias e Veterinárias da \\ Universidade Estadual Paulista Júlio de Mesquita Filho, Jaboticabal, SP, Brasil \\ ${ }^{3}$ Assistente de suporte acadêmico I da Faculdade de Ciências Agrárias e Veterinárias da Universidade Estadual Paulista \\ Júlio de Mesquita Filho, Jaboticabal, SP, Brasil. \\ ${ }^{4}$ Professores Doutores da Faculdade de Ciências Agrárias e Veterinárias da Universidade Estadual Paulista Júlio de \\ Mesquita Filho, Jaboticabal, SP, Brasil. - samara@fcav.unesp.br
}

\begin{abstract}
O vírus respiratório sincicial bovino (BRSV) é um dos principais patógenos que acometem o sistema respiratório de bovinos jovens, causando sérios prejuízos econômicos. Dados sobre sua epidemiologia e ocorrência em animais até um ano de idade são escassos na literatura brasileira. Assim, este estudo teve como objetivo determinar a ocorrência da atividade viral do BRSV em três rebanhos leiteiros soropositivos, por meio do monitoramento sorológico de bezerros, desde o primeiro dia de vida até os animais completarem um ano, utilizando a técnica de vírusneutralização. Os resultados mostraram que, nos animais das propriedades A e B, os títulos de anticorpos aumentaram nos primeiros meses,
\end{abstract}

\section{RESUMO}

PALAVRAS-CHAVE: atividade viral; monitoramento; título de anticorpos; vírus-neutralização; vírus respiratório sincicial bovino.

\section{BOVINE RESPIRATORY SYNCYTIAL VIRUS (BRSV) ACTIVITY IN DAIRY CALVES}

\section{ABSTRACT}

Bovine respiratory syncytial virus (BRSV) is one of the major pathogens affecting the respiratory system of young cattle, causing serious economic losses. Data on its epidemiology and occurrence in animals under oneyear of age are still scarce in the literature. This study aimed to determine the occurrence of viral activity in three of BRSV seropositive dairy herds (A, B, and C), by serological monitoring of calves from the first day of life until the age of one year, by virus neutralization test. Results showed that in animals from farms A and B, antibody titers increased in the first month, characterizing passive transfer of immunity through colostrums. Over time, the titers decreased till total absence in the sixth and eighth months respectively and then antibodies titration increased in the final months of the study, probably due to natural infection. On 
property C, although there was a similar antibodies' dynamics to the others, a period of total absence did not occurred, suggesting that animals may have been infected in the first months of life, despite the presence of colostral antibodies. This study demonstrated fluent BRSV activity amongst animals in all properties.

KEYWORDS: antibody titer; bovine respiratory syncytial virus; screening; viral activity; virus neutralization.

\section{INTRODUÇÃO}

O vírus respiratório sincicial bovino (BRSV) é considerado um importante agente patogênico que está associado a episódios de doença respiratória, especialmente em animais jovens. Faz parte do complexo doença respiratória bovina e é responsável por determinar grandes prejuízos econômicos à bovinocultura em todo o mundo (BAKER et al., 1993).

Classificado como membro da família Paramyxoviridae, subfamília Pneumovirinae, gênero Pneumovirus (INTERNATIONAL COMMITTEE ON TAXONOMY OF VIRUSES, 2011), o BRSV possui fita única de RNA como material genético e é envelopado. Por essa característica, é considerado um vírus muito sensível às condições ambientais (STOTT \& TAYLOR, 1985; BAKER et al., 1993).

A infecção pelo BRSV ocorre em animais de todos os tipos de exploração pecuária de bovinos, sendo que em áreas endêmicas, a doença clínica é mais frequente em animais jovens, com menos de 12 meses de idade. Animais adultos infectados de forma inaparente constituem-se na principal fonte de infecção para esses animais. $\mathrm{O}$ vírus é transmitido para bovinos suscetíveis por meio de secreções respiratórias e aerossóis, tanto por contato direto, quanto indireto mediado por fômites (STOTT et al., 1980; BAKER et al., 1993).

Em consequência da proteção atribuída pelos anticorpos de origem materna, bezerros com menos de um mês de idade geralmente apresentam a forma mais branda da enfermidade. Entretanto, devido ao decréscimo dos anticorpos colostrais, entre um e três meses de idade, a infecção tende a ser mais severa. Os anticorpos maternos não são eficientes para proteger os animais contra uma infecção pelo BRSV, porém o aparecimento e a severidade das manifestações clínicas são inversamente proporcionais aos níveis de anticorpos que o animal possui (KIMMAN et al., 1988).

Estudos envolvendo o monitoramento sorológico de bezerros já foram realizados nos Estados Unidos (BAKER et al., 1986; KIMMAN et al., 1988). BAKER et al. (1986) mostraram que o período médio de duração dos anticorpos de origem colostral era de 99 dias e a variação de 30 dias, no mínimo, e de 208 dias, no máximo. Essa questão é importante, pois a persistência de anticorpos maternos pode inviabilizar medidas de profilaxia, como a vacinação. No entanto, outros métodos de profilaxia relacionados ao manejo podem ser utilizados, como a separação entre animais jovens e adultos e, ainda, o alojamento dos bezerros individualmente (KIMMAN \& WESTENBRINK, 1990).

Em nosso país, apesar de alguns estudos determinarem a ocorrência do BRSV nos rebanhos por meio de testes sorológicos (DOMINGUES et al., 2002), pouco se sabe sobre a epidemiologia do vírus no Brasil, e ainda não existem pesquisas relacionadas ao monitoramento de títulos de anticorpos em bezerros até um ano de idade. Devido a isso, este estudo foi realizado com o objetivo de determinar a ocorrência da atividade viral em três rebanhos leiteiros soropositivos para o BRSV da região noroeste do Estado de São Paulo, por meio da análise do soro sanguíneo de bezerros, desde o primeiro dia de vida até os animais completarem 12 meses.

\section{MATERIAL E MÉTODOS}

O estudo foi conduzido em três propriedades rurais que criavam bovinos para a produção de leite, em regime de confinamento, com predomínio da raça holandesa. Os rebanhos estavam localizados em três municípios situados na região noroeste do Estado de São Paulo. A propriedade A, na cidade de Viradouro, possuía um rebanho de 140 animais; a propriedade B, localizada em Altinópolis, contava com 380 animais; e a propriedade $\mathrm{C}$, na cidade de Jaboticabal, com 80 animais. Todas as propriedades apresentavam condições semelhantes no que se refere ao manejo nutricional, trânsito de animais, ausência de vacinação contra BRSV e ocorrência de enfermidades.

Por meio de uma análise sorológica prévia com o emprego da técnica de vírus-neutralização (VN) em amostras representativas dos animais adultos (>1 ano) dessas propriedades, foram determinadas as seguintes prevalências de BRSV: 
$45,6 \%, 84,4 \%$ e $59,1 \%$, respectivamente, para as propriedades A, B e C (AFFONSO et al., 2011).

Para o monitoramento sorológico, dez bezerros de cada propriedade foram selecionados de forma aleatória. Esses animais, logo após o nascimento, permaneceram com suas mães para a ingestão de colostro. Caso isso não ocorresse espontaneamente, o colostro era ordenhado e administrado artificialmente por mamadeiras. Em seguida, os bezerros foram colocados em bezerreiros individuais, nos quais permaneceram por 60 dias até o desmame e, depois, foram transferidos para piquetes agrupados em lotes de acordo com a faixa etária. Amostras de sangue dos 30 bezerros foram colhidas nos dias 1,2 e 15 e depois mensalmente até os animais completarem 12 meses de idade. Para a colheita de sangue, foram utilizados tubos tipo Vacutainer ${ }^{\circledR}$ de $10 \mathrm{~mL}$, sem anticoagulantes, e agulhas hipodérmicas descartáveis. Dessa forma, o material foi transportado para o laboratório, centrifugado por 15 min a $1.800 \mathrm{G}$, e o soro separado em alíquotas de $1 \mathrm{~mL}$, em tubos tipo Eppendorf ${ }^{\circledR}$, que permaneceram armazenados em freezer a $-20^{\circ} \mathrm{C}$ até o momento de serem testados.

Para a pesquisa e titulação de anticorpos contra o BRSV nos soros dos animais foi utilizada a $\mathrm{VN}$ de acordo com protocolo proveniente do Laboratório de Viroses de Bovídeos, do Instituto Biológico de São Paulo, SP, descrito por AFFONSO (2010). Como antígeno foi utilizada uma amostra de BRSV padrão estrangeira (ATCC VR-1485), gentilmente cedida pela Dr $^{\mathrm{a}}$ Edviges Maristela Pituco, responsável técnica pelo Laboratório de Viroses de Bovídeos do Instituto Biológico de São Paulo, SP.

As amostras foram previamente inativadas em banho-maria a $56^{\circ} \mathrm{C}$ por 30 minutos e depois examinadas em duplicata pelo teste de VN. O teste foi realizado em microplacas de 96 cavidades com diluições de soro a partir de 1:2 até a diluição 1:1024. O antígeno, anteriormente titulado pelo método de REED \& MUENCH (1938), e ajustado a uma concentração de $200 \mathrm{TCID}_{50}$ foi adicionado nas cavidades que continham soro. A mistura sorovírus foi incubada por 1 hora em temperatura de $37^{\circ} \mathrm{C}$ e, em seguida, foram adicionadas células de linhagem contínua de rins de bovino Madin \& Darby bovine kidney (MDBK, ATCC CCL-22), cultivadas em meio essencial mínimo sem antibióticos (MEM; GIBCO BRL), e adicionadas de $10 \%$ de soro fetal bovino (SFB; CULTILAB). As microplacas foram incubadas em estufa com tensão de $\mathrm{CO}_{2}$ controlada a $5 \%$, em temperatura de $37^{\circ} \mathrm{C}$ por um período de 96 horas.

O título foi expresso como o inverso da diluição capaz de neutralizar as 200 TCID $_{50}$, calculado por meio de média geométrica. Após as médias serem efetuadas, os valores dos títulos foram transformados em logaritmo de base 10. As amostras consideradas positivas foram aquelas que inibiram o efeito citopatogênico do vírus a partir da diluição 1:2, ou seja, títulos maiores ou iguais a 0,30, correspondendo ao logaritmo decimal da primeira diluição (1:2).

\section{RESULTADOS E DISCUSSÃO}

A presença de anticorpos contra determinadas doenças em bezerros muito jovens está relacionada, em um primeiro momento, à transferência passiva de anticorpos maternos através do colostro. No caso do BRSV, os anticorpos de origem colostral em bezerros permanecem no organismo, em média, por aproximadamente três meses (BAKER et al., 1986). No entanto, esses anticorpos não são suficientes para proteger os animais contra uma infecção natural pelo vírus, apesar de a ocorrência da enfermidade e severidade dos sinais clínicos estarem diretamente relacionadas com a quantidade de anticorpos específicos circulantes (KIMMAN et al., 1988).

Os resultados do presente estudo, incluindo as três propriedades, estão apresentados na Figura 1. Pode ser observado que, com algumas variações, num primeiro momento são identificados anticorpos nos soros desses animais, que devem ter origem colostral. No decorrer das análises, os títulos de anticorpos foram decrescendo até o completo desaparecimento em alguns animais em determinados períodos. Logo após, os anticorpos foram novamente detectados, inclusive com aumento na média dos títulos dos bezerros até o final do estudo, quando eles completaram 12 meses de idade, provavelmente devido ao contato com vírus de campo. 


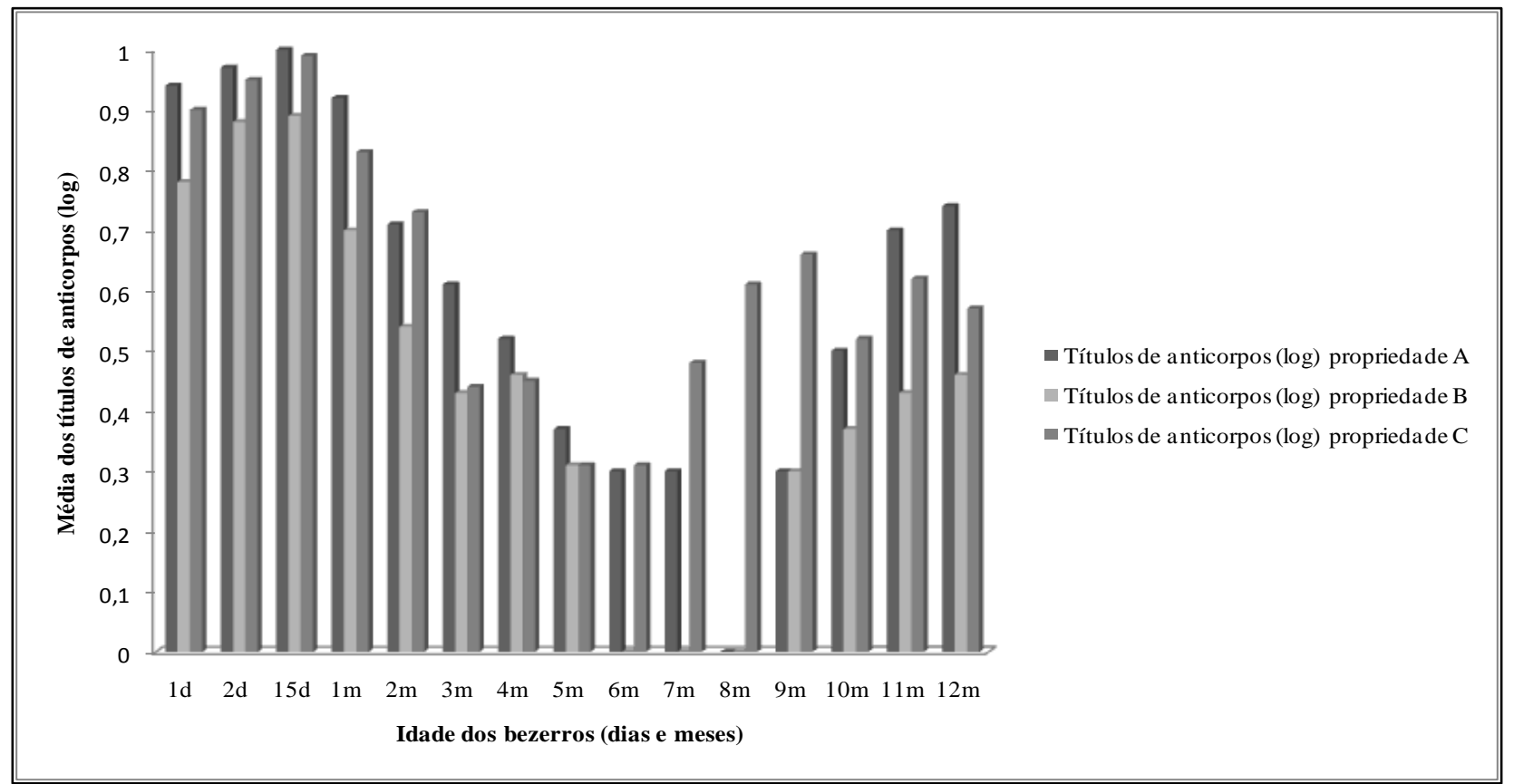

FIGURA 1. Médias dos títulos de anticorpos neutralizantes (log) para o BRSV determinados pela análise na VN de amostras sanguíneas de bezerros provenientes das propriedades dos respectivos municípios (A em Viradouro, B em Altinópolis e C em Jaboticabal) do Estado de São Paulo.

Os resultados referentes aos títulos de anticorpos neutralizantes para o BRSV nos soros sanguíneos de bezerros, determinados por meio do teste de VN para a propriedade A estão apresentados na Tabela 1. Pela análise das médias, os títulos foram crescentes desde o nascimento até os 15 dias de idade e começaram a decair a partir do primeiro mês de vida. Em média, o título foi negativado no oitavo mês. A partir do nono mês, os animais voltaram a apresentar o título mínimo $(0,30)$, que foi aumentando com ligeira elevação mensal nos meses subsequentes.

A análise dos dados de cada animal revelou que o menor tempo de duração dos anticorpos de origem colostral foi de quatro meses, e o maior de oito meses, com média de 5,6 meses entre os animais que se tornaram negativos no monitoramento. Alguns bezerros não se tornaram negativos no teste ao longo do tempo, o que dificultou deduzir quando ocorreu o desaparecimento dos anticorpos colostrais. A queda do título para níveis mínimos e a imediata elevação sugere que, mesmo ocorrendo o desafio com o vírus selvagem, a presença dos anticorpos maternos impediu a replicação viral com consequente produção de título infeccioso. Porém, tão logo eles desapareceram, foram substituídos por títulos relativos à infecção.

Apesar da prevalência de BRSV encontrada nos animais adultos dessa propriedade ser menor que as demais (45,6\%, AFFONSO et al., 2011), os bezerros foram os que apresentaram os maiores títulos de anticorpos, do início ao final do estudo.

Mesmo apresentando a maior persistência de anticorpos colostrais (período de oito meses), alguns bezerros dessa propriedade foram acometidos por doença respiratória, sendo a enfermidade confirmada em animais de todas as idades. Como foi evidenciada a infecção pelo BRSV por meio dos exames sorológicos, esse pode ter sido uma das causas dessas doenças.

Para a propriedade $\mathrm{B}$, os títulos de anticorpos provenientes da análise dos soros dos dez bezerros estão na Tabela 2. Semelhante à propriedade anterior, de uma maneira geral, houve aumento dos títulos de anticorpos após o nascimento até o décimo quinto dia de idade. Após esse período, ocorreu uma diminuição gradativa dos títulos de anticorpos desses animais, do primeiro mês até o quinto mês de idade, dado diferente do observado na Propriedade A. Do sexto ao oitavo mês, os animais não apresentaram títulos para o BRSV, porém após o nono mês até o final do estudo foi observado um discreto aumento mensal nos títulos de anticorpos.

Nessa propriedade foi identificado o bezerro que apresentou o menor (um mês) e o maior (seis meses) período de persistência de anticorpos colostrais, com média de 4,7 meses entre os animais que se tornaram negativos ao longo do estudo. 
TABELA 1. Títulos de anticorpos neutralizantes (log) para o BRSV determinados em amostras sanguíneas de bezerros nascidos na propriedade A, município de Viradouro, Estado de São Paulo

\begin{tabular}{|c|c|c|c|c|c|c|c|c|c|c|c|c|c|c|c|}
\hline \multirow{2}{*}{$\begin{array}{l}\mathrm{N}^{\circ} \text { identificação } \\
\text { dos bezerros }\end{array}$} & \multicolumn{15}{|c|}{ "Idade dos bezerros } \\
\hline & $1 \mathrm{~d}$ & $2 \mathrm{~d}$ & $15 \mathrm{~d}$ & $1 \mathrm{~m}$ & $2 \mathrm{~m}$ & $3 \mathrm{~m}$ & $4 \mathrm{~m}$ & $5 \mathrm{~m}$ & $6 \mathrm{~m}$ & $7 \mathrm{~m}$ & $8 \mathrm{~m}$ & $9 \mathrm{~m}$ & $10 \mathrm{~m}$ & $11 \mathrm{~m}$ & $12 \mathrm{~m}$ \\
\hline 1 & 0,60 & 1,04 & 1,04 & 1,35 & 1,20 & 1,04 & 0,60 & 0,74 & 0,43 & 0,43 & 0,30 & 0,30 & 0,60 & 0,43 & 0,30 \\
\hline 2 & 1,35 & 1,20 & 1,20 & 1,04 & 0,43 & 0,43 & 0,60 & 0,30 & 0,30 & 0,30 & 0,30 & $\mathrm{~N}$ & 0,30 & 0,30 & 0,60 \\
\hline 3 & 1,20 & 1,17 & 0,90 & 1,04 & 0,60 & 0,60 & 0,60 & 0,60 & 0,60 & 0,54 & 0,30 & 0,30 & 0,43 & 0,60 & 0,60 \\
\hline 4 & 0,90 & 0,90 & 1,20 & 1,04 & 0,74 & 0,60 & 0,60 & 0,30 & 0,30 & 0,30 & 0,30 & 0,60 & 0,43 & 0,43 & 0,60 \\
\hline 5 & 1,20 & 1,04 & 1,04 & 0,74 & 0,60 & 0,60 & 0,43 & 0,43 & 0,30 & 0,30 & 0,30 & 0,30 & 0,74 & 0,60 & 0,90 \\
\hline 6 & 0,60 & 0,60 & 0,74 & 0,43 & 0,60 & 0,60 & 0,30 & $\mathrm{~N}$ & $\mathrm{~N}$ & $\mathrm{~N}$ & $\mathrm{~N}$ & $\mathrm{~N}$ & $\mathrm{~N}$ & 1,04 & 1,47 \\
\hline 7 & 0,43 & 0,74 & 0,74 & 0,74 & 0,90 & 0,43 & 0,30 & $\mathrm{~N}$ & $\mathrm{~N}$ & $\mathrm{~N}$ & $\mathrm{~N}$ & 0,60 & 0,30 & 0,60 & 0,43 \\
\hline 8 & 0,85 & 0,60 & 1,04 & 1,04 & 0,90 & 0,60 & 0,43 & 0,43 & 0,30 & 0,43 & 0,43 & 0,60 & 0,74 & 0,74 & 0,60 \\
\hline 9 & 1,04 & 1,04 & 0,74 & 0,74 & 0,43 & 0,60 & 0,60 & 0,43 & $\mathrm{~N}$ & $\mathrm{~N}$ & $\mathrm{~N}$ & 0,30 & 0,30 & 1,20 & 0,90 \\
\hline 10 & 1,20 & 1,35 & 1,35 & 1,04 & 0,74 & 0,60 & 0,74 & 0,43 & 0,43 & 0,43 & $\mathrm{~N}$ & $\mathrm{~N}$ & 1,20 & 1,04 & 1,04 \\
\hline Média & 0,94 & 0,97 & 1 & 0,92 & 0,71 & 0,61 & 0,52 & 0,37 & 0,30 & 0,30 & $0,19 *(\mathrm{~N})$ & 0,30 & 0,50 & 0,70 & 0,74 \\
\hline
\end{tabular}

*Títulos menores que 0,30 são considerados negativos na prova de VN. d - dias; m - meses; $\mathrm{N}$ - negativo;

TABELA 2. Títulos de anticorpos neutralizantes (log) para o BRSV, determinados em amostras sanguíneas de bezerros nascidos na propriedade B, município de Altinópolis, Estado de São Paulo.

\begin{tabular}{|c|c|c|c|c|c|c|c|c|c|c|c|c|c|c|c|}
\hline \multirow{2}{*}{$\begin{array}{l}\mathrm{N}^{\mathrm{o}} \\
\text { identificação } \\
\text { dos bezerros }\end{array}$} & \multicolumn{15}{|c|}{ Idade dos bezerros } \\
\hline & $1 d$ & $2 \mathrm{~d}$ & $15 \mathrm{~d}$ & $1 \mathrm{~m}$ & $2 \mathrm{~m}$ & $3 \mathrm{~m}$ & $4 \mathrm{~m}$ & $5 \mathrm{~m}$ & $6 \mathrm{~m}$ & $7 \mathrm{~m}$ & $8 \mathrm{~m}$ & $9 \mathrm{~m}$ & $10 \mathrm{~m}$ & $11 \mathrm{~m}$ & $12 \mathrm{~m}$ \\
\hline 1 & 0,60 & 0,74 & 0,60 & 0,30 & $\mathrm{~N}$ & $\mathrm{~N}$ & $\mathrm{~N}$ & $\mathrm{~N}$ & $\mathrm{~N}$ & $\mathrm{~N}$ & $\mathrm{~N}$ & 0,30 & 0,30 & 0,30 & 0,30 \\
\hline 2 & 0,60 & 0,60 & 0,85 & 0,90 & 0,60 & 0,43 & 0,30 & 0,30 & 0,30 & 0,43 & 0,30 & 0,60 & 0,60 & 0,60 & 0,60 \\
\hline 3 & 1,20 & 1,20 & 1,20 & 1,20 & 0,90 & 0,74 & 0,60 & 0,30 & 0,30 & $\mathrm{~N}$ & $\mathrm{~N}$ & $\mathrm{~N}$ & $\mathrm{~N}$ & 0,60 & 0,60 \\
\hline 4 & 0,60 & 1,04 & 0,60 & 0,30 & 0,60 & 0,43 & 0,60 & 0,30 & 0,43 & 0,30 & 0,30 & 0,30 & 0,60 & 0,30 & 0,43 \\
\hline 5 & 1,51 & 1,51 & 1,34 & 1,20 & 1,20 & 0,60 & 0,60 & 0,43 & $\mathrm{~N}$ & $\mathrm{~N}$ & 0,30 & 0,60 & 0,60 & 0,43 & 0,43 \\
\hline 6 & 0,60 & 0,90 & 0,90 & 0,74 & 0,30 & 0,43 & 0,30 & 0,30 & 0,30 & 0,30 & 0,30 & 0,30 & 0,30 & 0,60 & 0,60 \\
\hline 7 & 1,04 & 0,90 & 1,04 & 0,74 & 0,60 & 0,60 & 0,60 & 0,43 & 0,30 & $\mathrm{~N}$ & $\mathrm{~N}$ & $\mathrm{~N}$ & 0,30 & 0,30 & 0,43 \\
\hline 8 & 0,60 & 0,74 & 0,60 & 0,43 & 0,60 & 0,30 & 0,30 & $\mathrm{~N}$ & $\mathrm{~N}$ & $\mathrm{~N}$ & $\mathrm{~N}$ & 0,30 & 0,30 & 0,43 & 0,60 \\
\hline 9 & 0,30 & 0,60 & 1,20 & 0,60 & 0,30 & 0,30 & 0,74 & 0,43 & 0,43 & $\mathrm{~N}$ & $\mathrm{~N}$ & $\mathrm{~N}$ & 0,30 & 0,30 & 0,30 \\
\hline 10 & 0,74 & 0,60 & 0,60 & 0,60 & 0,30 & 0,43 & 0,60 & 0,60 & $\mathrm{~N}$ & $\mathrm{~N}$ & $\mathrm{~N}$ & 0,30 & 0,43 & 0,43 & 0,30 \\
\hline Média & 0,78 & 0,88 & 0,89 & 0,70 & 0,54 & 0,43 & 0,46 & 0,31 & $0,21 *(\mathrm{~N}$ & $0,10^{*}(\mathrm{~N}$ & $0,12 *(\mathrm{~N})$ & 0,30 & 0,37 & 0,43 & $\overline{0,46}$ \\
\hline
\end{tabular}

* Títulos menores que 0,30 são considerados negativos na prova de VN. $\mathrm{d}$ - dias; $\mathrm{m}$ - meses; $\mathrm{N}$ - negativo

Três bezerros não foram, em nenhum momento, negativos no teste, o que impossibilitou avaliar o momento em que deixaram de apresentar anticorpos de origem materna e passaram a ter títulos de anticorpos por possível indução antigênica.

Mesmo possuindo maior prevalência de BRSV (84,4\%, AFFONSO et al., 2011), os bezerros analisados não apresentaram títulos de anticorpos mais elevados do que os títulos observados nas outras duas propriedades. Pela análise mensal das médias dos títulos, durante três meses a média foi menor que 0,30 , ou seja, o teste foi negativo. Somente a partir do nono mês, houve aumento paulatinamente do título, até o último mês da pesquisa. De acordo com os registros, nessa propriedade poucos animais apresentaram problemas respiratórios. De acordo com diversos pesquisadores (CANCELLOTTI et al., 1980; BOHLENDER et al., 1982; VERHOEFF \& VAN NIEUSTADT, 1984), a indução de anticorpos contra o BRSV em bezerros pode ocorrer sem que os animais apresentem doença clínica. Dessa forma, os dados observados podem indicar que os animais em questão entraram em contato com o vírus, soroconverteram, mas só alguns apresentaram sinais clínicos.

Em relação à propriedade $\mathrm{C}, \mathrm{o}$ monitoramento dos títulos mostrou uma diferença marcante em relação às demais, pois em nenhum momento as médias mostraram total ausência de anticorpos (Tabela 3). As médias dos títulos de anticorpos dos bezerros mostraram que houve uma tendência crescente até os 15 dias e depois decrescente do primeiro mês até o quinto mês, com ligeiro aumento no quarto mês de idade. No quinto e sexto meses, os títulos permaneceram constantes, sem indicação de desaparecimento dos anticorpos, para, em seguida, já no sétimo mês, ocorrer um aumento nos títulos de forma crescente até o nono 
mês de idade dos bezerros. No décimo mês houve uma queda do título e, logo nos meses seguintes, os títulos voltaram a subir e tornaram a diminuir. Analisando individualmente os bezerros dessa propriedade, a maioria dos títulos dos animais em nenhum momento tornou-se negativa. Como já mencionado anteriormente, também nesse caso fica impossível distinguir anticorpos de origem materna daqueles provenientes de infecção. Alguns bezerros tornaram-se negativos no teste em algum momento da pesquisa, sendo o período mínimo de permanência de anticorpos colostrais encontrado de três meses e o máximo, de quatro meses, com tempo médio de 3,7 meses.

Apesar de a propriedade $\mathrm{C}$ ter apresentado prevalência intermediária de BRSV (59,09\%, AFFONSO et al., 2011), não houve período com total ausência de anticorpos. Conforme registros, nessa propriedade, os animais apresentaram esporadicamente sinais clínicos de doença respiratória, observados em todas as idades.

TABELA 3. Títulos de anticorpos neutralizantes (log) para o BRSV determinados em amostras sanguíneas de bezerros nascidos na propriedade C, município de Jaboticabal, Estado de São Paulo

\begin{tabular}{|c|c|c|c|c|c|c|c|c|c|c|c|c|c|c|c|}
\hline \multirow{2}{*}{$\begin{array}{l}\mathrm{N}^{\circ} \text { identificação dos } \\
\text { bezerros }\end{array}$} & \multicolumn{15}{|c|}{ Idade dos bezerros } \\
\hline & $1 \mathrm{~d}$ & $2 \mathrm{~d}$ & $15 d$ & $1 \mathrm{~m}$ & $2 \mathrm{~m}$ & $3 \mathrm{~m}$ & $4 \mathrm{~m}$ & $5 \mathrm{~m}$ & $6 \mathrm{~m}$ & $7 \mathrm{~m}$ & $8 \mathrm{~m}$ & $9 \mathrm{~m}$ & $10 \mathrm{~m}$ & $11 \mathrm{~m}$ & $12 \mathrm{~m}$ \\
\hline 1 & $\mathrm{~N}$ & $\mathrm{~N}$ & 0,43 & 0,43 & 0,30 & 0,30 & 0,30 & $\mathrm{~N}$ & $\mathrm{~N}$ & 0,30 & 0,30 & 0,90 & 1,20 & 1,20 & 1,20 \\
\hline 2 & 1,20 & 1,20 & 1,35 & 1,04 & 0,74 & 0,43 & 0,60 & 0,74 & 0,43 & 0,60 & 0,74 & 0,43 & 0,30 & 0,74 & 0,43 \\
\hline 3 & 0,60 & 1,04 & 1,51 & 1,04 & 1,04 & 0,43 & 0,43 & 0,43 & 0,43 & 0,30 & 0,30 & 0,60 & 0,43 & 0,30 & 0,30 \\
\hline 4 & 0,90 & 0,85 & 0,74 & 0,60 & 0,74 & 0,43 & 0,60 & 0,74 & 0,60 & 0,43 & 0,60 & 0,90 & 0,43 & 0,43 & 0,43 \\
\hline 5 & 1,20 & 1,20 & 1,20 & 0,85 & 0,60 & 0,60 & 0,60 & 0,60 & 0,30 & 0,30 & 0,43 & 0,74 & 0,30 & 0,43 & 0,30 \\
\hline 6 & 0,74 & 0,74 & 0,60 & 0,60 & 0,60 & 0,43 & 0,43 & 0,30 & 0,30 & 0,30 & 0,30 & 0,30 & 0,43 & 0,60 & 0,60 \\
\hline 7 & 1,95 & 2,11 & 1,95 & 1,65 & 1,17 & 0,90 & 0,90 & 0,30 & 0,30 & 0,90 & 0,74 & 0,60 & 0,90 & 0,74 & 0,60 \\
\hline 8 & 0,60 & 0,74 & 0,60 & 0,43 & 0,60 & 0,30 & 0,30 & $\mathrm{~N}$ & 0,43 & 1,04 & 0,90 & 0,74 & 0,52 & 0,60 & 0,60 \\
\hline 9 & 0,43 & 0,43 & 0,60 & 0,60 & 0,60 & 0,30 & 0,30 & $\mathrm{~N}$ & 0,30 & 0,60 & 0,60 & 0,60 & 0,43 & 0,60 & 0,60 \\
\hline 10 & 1,35 & 1,20 & 0,90 & 1,04 & 0,90 & 0,30 & $\mathrm{~N}$ & $\mathrm{~N}$ & $\mathrm{~N}$ & $\mathrm{~N}$ & 1,20 & 0,74 & 0,30 & 0,60 & 0,60 \\
\hline Média & 0,90 & 0,95 & 0,99 & 0,83 & 0,73 & 0,44 & 0,45 & 0,31 & 0,31 & 0,48 & 0,61 & 0,66 & 0,52 & 0,62 & 0,57 \\
\hline
\end{tabular}

$\mathrm{d}$ - dias; $\mathrm{m}$ - meses; $\mathrm{N}$ - negativo

Para BAKER et al. (1986), os anticorpos maternos não são capazes de proteger os bezerros contra uma infecção pelo BRSV. Por essa premissa, provavelmente ocorreu uma infecção dos bezerros com vírus de campo nos primeiros meses de vida, mesmo na presença de anticorpos maternos, o que pode caracterizar a dinâmica dos títulos observada nesta propriedade.

\section{CONCLUSÕES}

A sorologia realizada em etapas pareadas em animais jovens pode mostrar a mais recente atividade do agente viral em um determinado rebanho. No caso do presente estudo, a atividade viral foi confirmada pelo monitoramento sorológico de bezerros que, com algumas particularidades dentro de cada rebanho, constatou o declínio natural dos anticorpos contra o BRSV ao longo do tempo, desde o primeiro mês de vida. Em alguns animais, também foi possível estabelecer a duração da imunidade de origem colostral, devido ao desaparecimento dos títulos de anticorpos, porém, em outros bezerros, ela não pode ser determinada, provavelmente por ter ocorrido infecção pelo vírus de campo. Deste fato pode-se deduzir que a presença de anticorpos colostrais não impede a infecção dos animais. A detecção de títulos crescentes de anticorpos é um fator que comprova a atividade contínua de re-infecções pelo BRSV entre os animais, em todas as propriedades.

\section{AGRADECIMENTOS}

Os autores agradecem à $\operatorname{Dr}^{\mathrm{a}}$ Edviges Maristela Pituco e Dr ${ }^{a}$. Claudia Pestana Ribeiro do Instituto Biológico de São Paulo por fornecer a amostra viral, pelos protocolos e por toda a assistência dispensada. À FAPESP pelo auxílio 
concedido (Processo $\mathrm{n}^{\circ}$ 2008/56693-6) e ao CNPq pela bolsa de estudo (Processo n ${ }^{\circ}$ 561765/2008-1).

\section{REFERÊNCIAS}

AFFONSO, I. B. Monitoração da ocorrência do Vírus Respiratório Sincicial Bovino (BRSV) em plantéis leiteiros infectados pelo Herpesvírus Bovino Tipo 1. 2010, 47f. Dissertação (Mestrado em Medicina Veterinária Preventiva), Faculdade de Ciências Agrárias e Veterinárias, Universidade Estadual Paulista, Jaboticabal, $2010 . \quad$ Disponível em http://www.dominiopublico.gov.br/pesquisa/DetalheObra Download.do?select_action=\&co_obra $=173611 \&$ co_midi $\mathrm{a}=2$

AFFONSO, I. B.; GATTI, S. P.; ALEXANDRINO, B.; OLIVEIRA, M. C.; MEDEIROS, A. S. R.; BUZINARO, M. G.; SAMARA, S. I. Detection of antibodies against bovine respiratory syncytial virus (BRSV) in dairy cattle with different prevalences of bovine herpesvirus type 1 (BHV-1) in São Paulo State, Brazil. Semina: Ciências Agrárias, Londrina, v. 32, n. 1, p. 295-300, 2011.

BAKER, J. C.; AMES, T. R.; BELKNAP, E. B.; DUBOVI, E. J.; BRYSON, D. G.; KELLING, C. L. BRSV (bovine respiratory syncytial virus) infection: its pathogenesis, diagnosis, prevention and treatment. Veterinary Medicine, v. 88, p. 880-906, 1993.

BAKER, J. C.; AMES, T. R.; MARKHAM, R. J. F. Seroepizootiologic study of bovine respiratory syncytial virus in a dairy herd. American Journal of Veterinary Research, v. 47, n. 2, p. 240-245, 1986.

BOHLENDER, R. E.; MCCUNE, M. W.; FREY, M. L. Bovine respiratory syncytial virus infection. Modern Veterinary Practice, v. 63, p. 613-618, 1982.

CANCELOTTI, F. M.; CARLOTTO, F., GAGLIARDI, G. Some observations on respiratory syncytial bovine virus (RSBV) incidence in north-eastern Italy feedlot cattle. In: CONGRESS ON DISEASES OF CATTLE, 11. 1980, Haifa, Israel. Bergman Press, p. 355-358.

DOMINGUES, H. G.; CAMPALANS, J.; ALMEIDA, R. S.; COSWIG, L. T.; ARNS, C. W. Dot-enzyme linked immunosorbent assay as an alternative technique for the detection of bovine respiratory syncytial virus (BRSV) antibodies. Veterinary Research, v. 33, p. 397-404, 2002 .

INTERNATIONAL COMMITTEE ON TAXONOMY OF VIRUSES. Virus Taxonomy: 2011 release. Disponível em <talk.ictvonline.org/files/ictv_documents/m/msl/4090.asp $\mathrm{X}>$. Acesso em: mar.2012.

KIMMAN, T. G.; WESTENBRINK, F. Immunity to human and bovine respiratory syncytial virus. Archives of Virology, v. 112, n. 1-2, p. 1-25, 1990.

KIMMAN T, G.; ZIMMER, G. M.; WESTENBRINK, F.; MARS, J.; VANLEEUWEN, E. Epidemiological-study of bovine respiratory syncytial virus-infections in calves: Influence of maternal antibodies on the outcome of disease. Veterinary Record, v. 123, n. 4, p. 104-109, 1988 .

REED, L. J.; MUENCH, H. A simple method of estimating 50 per cent end point. American Journal of Hygiene, v. 27, n. 3, p. 493-497, 1938.

STOTT, E. J.; TAYLOR, G. Respiratory syncytial virus: brief review. Archives of Virology, v. 84, p. 1-52, 1985.

STOTT, E. J.; THOMAS, L. H.; COLliNS, A. P.; CROUCH, S.; JEBBETT, J.; SMITH, G. S.; LUTHER, P. D.; CASWELL, R. A survey of virus infections of the respiratory tract of cattle and their association with disease. Journal of Hygiene, v. 85, p. 257-270, 1980.

VALARCHER, J. F.; TAYLOR, G. Bovine respiratory syncytial virus infection. Veterinary Research, v.38, n. 2, p. 153-180, 2007.

VAN DER POEL, W. H.; SCHRIJVER, R. S.; MIDDEL, W. G.;KRAMPS, J. A.; BRAND, A.; VAN OIRSCHOTVAN, J. T. Experimental reproduction of respiratory disease in calves with non-cell-culturepassaged bovine respiratory syncytial virus. Veterinary Quarterly, The Hague, v. 18, n. 3, p. 81-86, 1996.

VERHOEFF, J.; VAN NIEUSTADT, A. BRS virus, PI3 virus and BHV-1 infections of young stock on selfcontained dairy farms: epidemiological and clinical findings. Veterinary Record, v. 114, p. 288-293, 1984. 